Schweiz. Z. Tuberk. 1959;16:277-278

\title{
An die Teilnehmer des XV. Internationalen Tuberkulose- Kongresses in Istanbul
}

Vom 11. bis 18. September 1959 findet in Istanbul der XV. Internationale Tuberkulose-Kongreß statt. Internationale Zusammen-künfte dienen dem Austausch der Erfahrungen und Forschungsergebnisse in der Tuberkulose-Erfassung, Bekämpfung und Behand-lung, aber auch der Vertiefung persönlicher freundschaftlicher Be-ziehungen. Die zeitliche Lücke zwischen den Zusammenkünften überbrücken die Fachzeitschriften. Die Schweízerísche Zeítschríft für Tuberkulose und Pneumonologíe hat sich durch ihre Viersprachigkeit in den besonderen Dienst dieser internationalen Vermittlung gestellt. Schriftieitung und Verlag freuen sich, den

Teilnehmern des XV. Internationalen Tuberkulose-Kongresses in Istanbul eine Sonder-nummer zu überreichen.

Aux Participants du XV Congrès International de la Tuberculose

à Istanbul

Le XVe Congrès International de la Tuberculose aura lieu du 11 au 18 septembre 1959 à Istanbul. Les congrès internationaux servent à $\Gamma$ échange de communications sur les résultats des re-cherches scientifiques sur la tuberculose, de sa prophylaxie et de son traitement, mais ils permettent en outre de favoriser et d'ap-profondir des contacts personnels et amicaux. Entre ces reunions, les publications périodiques spécialisées assurent la continuité de ces échanges. La Revue Suísse de la Tuberculose et de Pneumologíe s'est mise tout particulièrement au service de ces relations Internationales par $\Gamma$ utilisation de quatre languages. Sa redaction et ses

Schweiz. Z. Tubrek. Vol. 16, No. 5 (1959) 21

278

éditeurs se font un plaisir d'en oífrir un numéro special aux participants du XVe Congrès International de la Tuberculose à Istanbul.

Ai Partecípí del $X^{\circ}$ Congresso Internazíonale della TBC ad Istanbul

Dal 11 al 18 Settembre ha luogo ad Istanbul il XV Congresso Internazionale della TBC. Le riunioni internazionali servono allo scambio di esperienza e risultati di ricerche nella conoscenza della TBC, cura e lotta. Non meno importante è la miglior conoscenza personale e

Tallacciamento di relazioni amichevoli. Lo spazio vuoto tra queste manifestazioni è riempito dalle riviste professionali. La rivista svizzera della TBC e Pneumologia si è posta al servizio speciale di questa collaborazione internazionale grazie ai suoi lavori in 4 lingue. La redazione e la tipografia editrice hanno il piacere di offrire ai partecipanti del $\mathrm{XV}^{\circ}$ Congresso Internazionale della TBC un numero speciale.

To the Members of the X Vth International Congress of Tuberculosis in Istanbul

The XVth International Congress of Tuberculosis is being held in Istanbul from September 11th to 18 th, 1959. Such international meetings facilitate the exchange of ideas and results of research on comprehension, prevention and treatment of tuberculosis, and furthermore promote personal contacts between the participants. During the periods between such meetings, international 
periodicals serve as a link between the scientists from different parts of the world. The Swiss Journal of Tuberculosis and Pneumonology stresses its international character by publishing papers in four languages. Editors and Publishers have pleasure in dedicating this Special Number to the members of the XVth International Congress of Tuberculosis in Istanbul. 